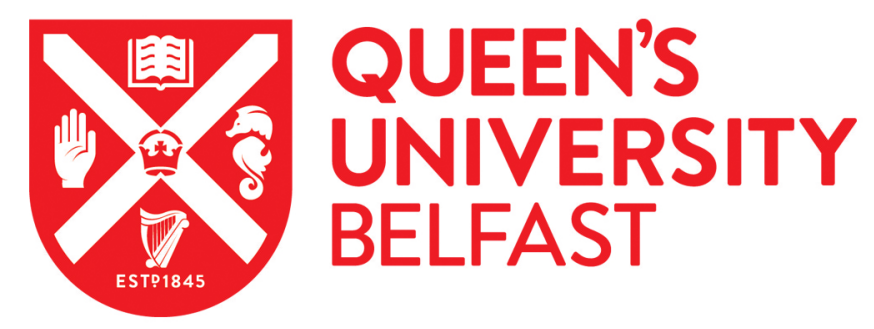

\title{
Investigation of heat exchanger inclination in forced-draught air-cooled heat exchangers
}

Kennedy, I. J., Spence, S. W. T., Spratt, G. R., \& Early, J. M. (2013). Investigation of heat exchanger inclination in forced-draught air-cooled heat exchangers. Applied Thermal Engineering, 54(2), 413-421.

https://doi.org/10.1016/j.applthermaleng.2013.02.013

Published in:

Applied Thermal Engineering

Document Version:

Peer reviewed version

Queen's University Belfast - Research Portal:

Link to publication record in Queen's University Belfast Research Portal

\begin{abstract}
Publisher rights
This is the author's version of a work that was accepted for publication in Applied Thermal Engineering. Changes resulting from the publishing process, such as peer review, editing, corrections, structural formatting, and other quality control mechanisms may not be reflected in this document. Changes may have been made to this work since it was submitted for publication. A definitive version was subsequently published in Applied Thermal Engineering, [VOL 54, ISSUE 2, (2013)]
\end{abstract}

\section{General rights}

Copyright for the publications made accessible via the Queen's University Belfast Research Portal is retained by the author(s) and / or other copyright owners and it is a condition of accessing these publications that users recognise and abide by the legal requirements associated with these rights.

Take down policy

The Research Portal is Queen's institutional repository that provides access to Queen's research output. Every effort has been made to ensure that content in the Research Portal does not infringe any person's rights, or applicable UK laws. If you discover content in the Research Portal that you believe breaches copyright or violates any law, please contact openaccess@qub.ac.uk. 


\section{Accepted Manuscript}

Investigation of heat exchanger inclination in forced-draught air-cooled heat exchangers

Ian J. Kennedy, Stephen W.T. Spence, Gordon R. Spratt, Juliana M. Early

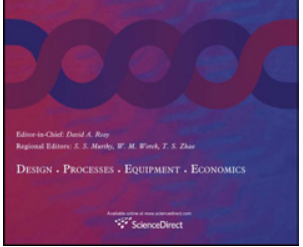

PII: S1359-4311(13)00118-X

DOI: 10.1016/j.applthermaleng.2013.02.013

Reference: ATE 4632

To appear in: Applied Thermal Engineering

Received Date: 22 June 2012

Accepted Date: 6 February 2013

Please cite this article as: I.J. Kennedy, S.W.T. Spence, G.R. Spratt, J.M. Early, Investigation of heat exchanger inclination in forced-draught air-cooled heat exchangers, Applied Thermal Engineering (2013), doi: 10.1016/j.applthermaleng.2013.02.013.

This is a PDF file of an unedited manuscript that has been accepted for publication. As a service to our customers we are providing this early version of the manuscript. The manuscript will undergo copyediting, typesetting, and review of the resulting proof before it is published in its final form. Please note that during the production process errors may be discovered which could affect the content, and all legal disclaimers that apply to the journal pertain. 
Highlights

- Inclination only makes a small difference to thermal performance of ACHE

- Increasing plenum depth only is slightly more effective - $1 \%$ benefit over baseline

- The flow tends to move to one side as the heat exchanger is inclined

- This side is a good location for a performance limiting heat exchanger 


\title{
Investigation of heat exchanger inclination in forced-draught air-cooled heat exchangers
}

\author{
Ian J. Kennedy ${ }^{a} *$ \\ ikennedy03@qub.ac.uk \\ +44 (0) 2890974380 \\ Stephen W.T. Spence ${ }^{\mathrm{a}}$ \\ s.w.spence@qub.ac.uk \\ Gordon R. Spratt ${ }^{\mathrm{b}}$ \\ gspratt@fgwilson.com \\ Juliana M. Early ${ }^{\text {a }}$ \\ j.early@qub.ac.uk \\ *Author for correspondence
}

School of Mechanical and Aerospace Engineering,

Queen's University Belfast,

Ashby Building,

Stranmillis Road,

Belfast,

Northern Ireland,

BT9 5AH

b

FG Wilson (Engineering) Ltd

Old Glenarm Road

Larne

Co. Antrim

Northern Ireland

BT40 1EJ

\section{Abstract}

The purpose of this study is to determine the influence of inclining the heat exchanger relative to the fan in a forced draught air cooled heat exchanger. Since inclination increases plenum depth, the effect of inclination is also compared with increasing plenum depth without inclination. The experimental study shows that inclination improves thermal performance by only $0.5 \%$, when compared with a baseline noninclined case with a shallow plenum. Similarly, increasing plenum depth without inclination has a thermal performance benefit of approximately $1 \%$. The numerical study shows that, as the heat exchanger is inclined, the low velocity core at the centre of the heat exchanger moves to one side.

\section{Keywords}

Inclination, Forced-draught air-cooled heat exchanger

\section{Introduction}

An air cooled heat exchanger (ACHE) is a device used to transfer heat energy from a hot fluid to ambient air. It typically consists of an axial fan and heat exchanger, separated by an enclosed region known as a plenum chamber. This paper is concerned with forced draught ACHEs where, as the name suggests, the fan forces air through the heat exchanger. 
In some industrial forced draught ACHEs, such as those in the generating set industry, the flow must turn through $90^{\circ}$ after exiting the heat exchanger. This is illustrated in Figure 1, and is the motivation for investigation of inclination of the heat exchanger.

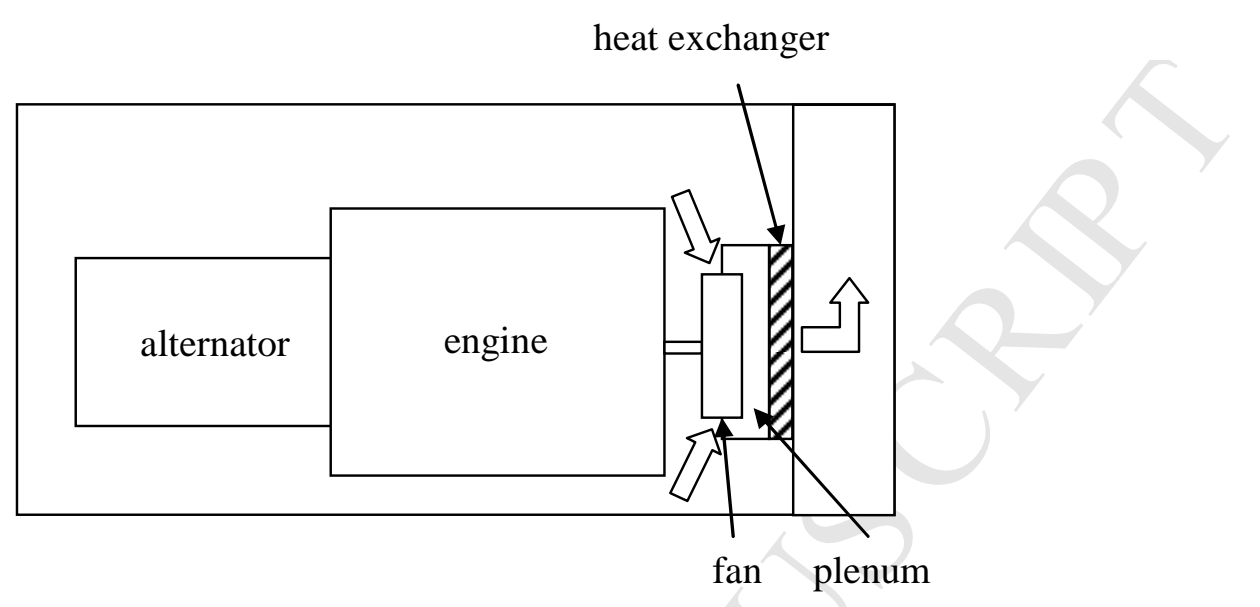

Figure 1 Cooling system in an enclosed generating set

In cooling systems such as in Figure 1, due to packaging constraints, the plenum depths are typically shallower than the critical minimum as found by Meyer and Kröger [1]. Furthermore, the axial fan often operates in the mixed flow region of the fan characteristic, due to the restrictive nature of the system, as shown in Figure 2. These two factors lead to a reduction in the thermal performance of the system.

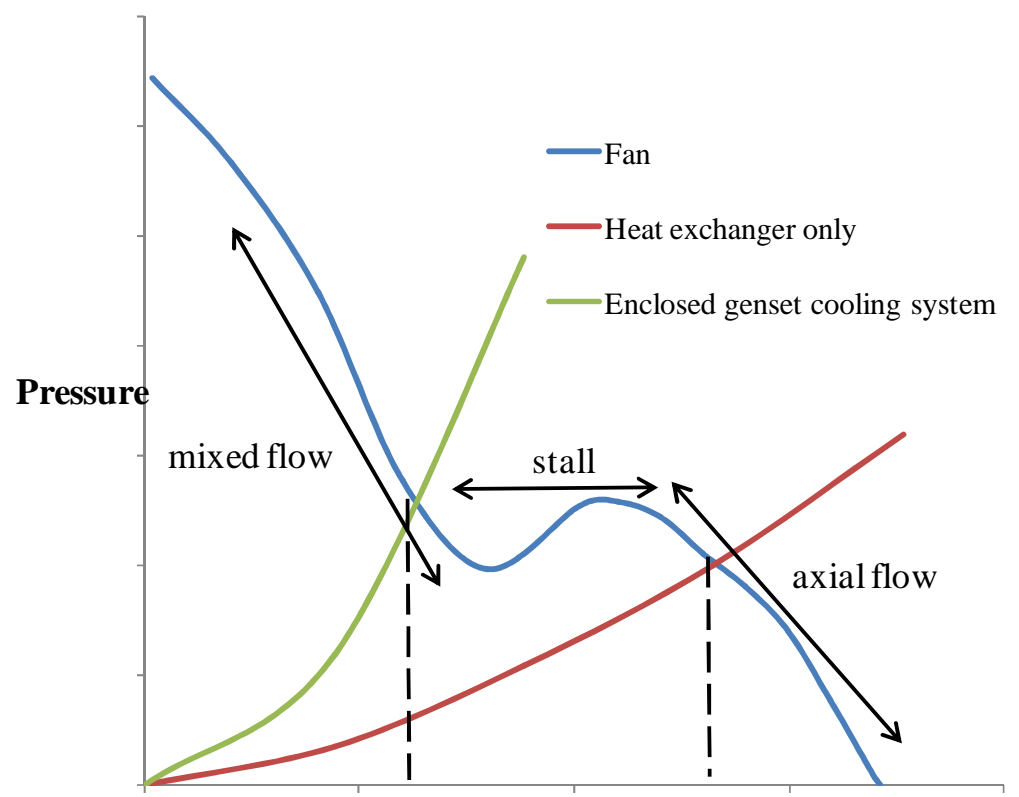

Flow rate

Figure 2 Operating point on fan characteristic 
In this paper, the influence of inclination of the heat exchanger relative to the fan is investigated. Inclination affects the thermal performance in that it affects the flow rate through the heat exchanger, for a given fan speed and atmospheric conditions. It also affects the distribution of flow through the heat exchanger, which impacts thermal performance.

Various studies have shown that maldistribution of flow in ACHEs has a small impact on performance. . Meyer and Kröger [1] found that flow maldistribution affected thermal performance by a few percent, at plenum depths of about 0.3 fan diameters. Berryman and Russell [2] also noted that maldistribution of airflow led to a loss in thermal performance of a few percent. They used velocity data with variation in it that they considered to be as great as could be expected in practice, even for very shallow plenums. Beiler and Kröger [3] had similar findings, with a plenum 0.45 fan diameters deep.

Most studies of maldistribution of flow are focussed on profiles from ACHEs where the fan operates in the axial flow part of the fan characteristic. Other studies using artificially generated velocity profiles have found larger thermal performance reductions, some by more than $10 \%$. For example, Rabas [4] investigated the impact of one and two dimensional inlet flow distributions on the performance of an air cooled condenser. The largest reduction in thermal performance was less than 7\%. Fagan [5] analytically investigated the effects of linear and step air flow maldistributions on the thermal performance of air to refrigerant single and multi row heat exchangers. A step distribution with a velocity deviation of $75 \%$ of the average face velocity gave the highest thermal performance reduction of about $15 \%$. T'Joen et al. [6] experimentally studied the impact of non uniform flow on the performance of a fin and tube heat exchanger. They investigated different inlet velocity profiles and found that the largest reduction in thermal performance was $8 \%$ for a linear profile.

Some research work has been carried out on flow through vehicle heat exchangers. For example, Hallqvist [7] simulated the flow through a truck using CFD. The fan was simulated using a multiple reference frame technique. He found that non-uniform flow reduced the performance of the cooling system by $4.4 \%$ when compared with a uniform flow distribution.

The flow rate through the system will change with inclination due to a number of factors. Firstly, the performance of the fan will change due to its interaction with the heat exchanger. This is known as the system or installation effect [8]. Secondly, it has been noted that pressure is recovered in the plenum, as some of the kinetic energy of the air exiting the fan is converted to pressure. This pressure recovery is a function of the plenum chamber depth [1], which will change when the heat exchanger is inclined. More pressure recovery leads to a greater flow rate.

Other factors will affect the flow rate through the system. One such factor is the distribution of flow through the heat exchanger. This will change with inclination, affecting the pressure drop across the heat exchanger, and hence the flow rate through the system. Hallqvist [7] noted that uniformity of the flow affects the pressure loss across a heat exchanger, due to the fact that pressure loss varies non-linearly with velocity. He also found that pressure losses increase with increasing non-uniformity. The final effect on flow rate is the influence of inlet losses as the flow enters the heat exchanger. The angle of incidence of the flow entering the heat exchanger will change with inclination. Flow approaching at an angle gives a region of separated flow at the entrance of the airside passages of the heat exchanger. Studies have been conducted with heat exchangers inclined in a duct with uniform inlet flow. They have shown that losses increase significantly at inclination angles of $60^{\circ}$ or more. Nichols [9] investigated inclining an intercooler at various angles to its inlet duct. The losses increased only slightly with inclination up to $70^{\circ}$. Above $70^{\circ}$ they increased rapidly. The distribution of flow was also observed to be fairly uniform up to this angle. Kanematsu and Murakami [10] investigated inclining different heat exchangers in a wind tunnel. Inclination angles of $0^{\circ}, 45^{\circ}, 60^{\circ}$ and $80^{\circ}$ were tested. The pressure drop increased significantly between $60^{\circ}$ and $80^{\circ}$ inclination. Meyer and Kröger [11] also found that losses due to inclination became significant at an inclination angle of approximately $70^{\circ}$. Elgowalny [12] numerically investigated nonuniform flow through tube fin heat exchangers in air conditioning and heat pump systems. The main finding was that the effect of flow maldistribution was more pronounced on the mass averaged pressure drop across the heat exchanger than on the area averaged heat transfer coefficient. The pressure drop for nonuniform flow was approximately $9 \%$ more than for uniform flow, but the heat transfer coefficient was 
only about $1 \%$ less for nonuniform flow than for uniform flow. More recently, Song et al. [13] studied the effects of nonuniform flow on the performance of a multi circuit evaporator. They found that the nonuniform flow reduced the capacity by approximately $8 \%$. They also noted from their literature review that air flow maldistribution has more notable effects on multi circuit evaporators and condensers than on single circuit ones.

In summary, the literature on inclining heat exchangers is predominantly focussed on heat exchangers inclined in a duct, with uniform inlet flow. The main findings are that pressure losses increase with inclination, with significant increases occurring at inclination angles greater than $60^{\circ}$. Heat transfer coefficients in most cases are not significantly affected by inclination. For example, Kim et al. [14] experimentally investigated inclining louvered fin heat exchangers in a duct. They investigated inclination angles up to $60^{\circ}$ and found heat transfer coefficient did not decline significantly with inclination. Kim et al. [15] also had similar findings. To the author's knowledge, there are no studies available in the literature on inclining a single heat exchanger relative to an axial fan.

Some of the preceding discussion is only relevant to inclination of forced draught systems, as opposed to induced draught systems. Induced draught systems generally do not have flow approaching the heat exchanger inlet face at significant angles of incidence. They also do not have pressure recovery in their plenums. The performance of induced draught systems is likely to be much less sensitive to inclination of the heat exchanger, due to a number of different factors. The main reason is the absence of plenum pressure recovery. With forced draught systems this occurs and it has been shown that this is very sensitive to plenum depth, which of course can change with inclination. Another reason is that induced draught systems generally have more uniform flow through the heat exchanger [3], which is unlikely to be improved significantly by inclination.

In this paper, an isothermal experimental study was conducted to investigate the effects of inclination on performance. The study included increasing the depth of the plenum without inclination. It was conducted across the fan characteristic, including mixed flow operating points. The experimental study was complemented by a numerical study using CFD to gain an understanding of the flow patterns in the plenum and how they change with inclination angle.

\section{Experimental study}

An isothermal experimental study was conducted in order to determine the effects of inclination on ACHE performance.

\subsection{Experimental equipment}

A fan test rig was manufactured according to ISO 5801:2008 [16]. This is shown schematically in Figure 3. The means of inclination is also illustrated in Figure 3. The heat exchanger was inclined about its top edge, and the cross sectional area of the heat exchanger for all tests was constant. 


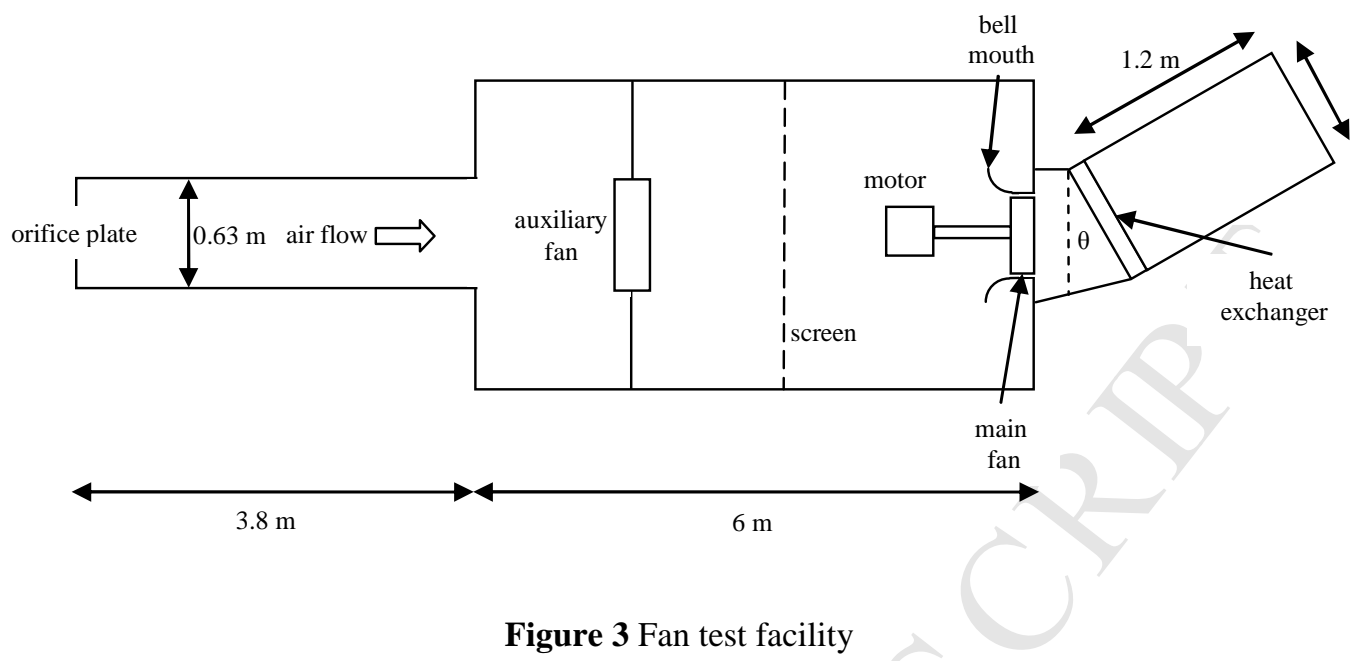

The mass flow rate through the test rig was measured using an orifice plate in an installation according to ISO 15377 [17]. An auxiliary fan was used to control the flow rate through the system and to boost the performance of the main fan. A screen after the auxiliary fan was used to provide uniform flow into the main fan. An outlet duct was constructed after the heat exchanger, to make numerical modelling of the system simpler. The main fan used was an axial fan with a sickle type blade profile. The fan casing diameter $d_{f c}$ was $420 \mathrm{~mm}$. The heat exchanger investigated was a louvered fin type with a single row of flat tubes. The heat exchanger measured $470 \mathrm{~mm}$ by $470 \mathrm{~mm}$ in the plane perpendicular to the air flow.

A data acquisition system was used to collect and process the data from the test rig. This included a program which calculated the flow rate through the system based on the pressure drop across the orifice plate.

\subsection{Experimental measurements and procedure}

In the experiments, the flow rate through the system was fixed and the pressure difference between the fan inlet and heat exchanger outlet was measured. The fan static pressure rise and the heat exchanger static pressure drop were not measured directly on the complete system. This is because the static pressure in the plenum varies significantly in space, making an average of the pressure downstream of the fan very difficult to measure directly [18]. Instead, both characteristics were obtained as discussed in the following paragraphs.

The fan characteristic was measured by removing the exit assembly consisting of the shroud, heat exchanger and exit duct, changing the flow rate and measuring the pressure rise across the fan. Measurements of the ACHE were taken at five different flow rates on the fan characteristic, in order to determine the effects of inclination at different operating points.

The heat exchanger characteristic used was based on supplier measurements. The data was checked by removing the main fan and using the auxiliary fan to drive the flow through the heat exchanger. A plenum 0.8 fan diameters deep was used and the pressure loss across the heat exchanger was measured for different flow rates. The two sets of measurements showed good agreement and gave confidence in the supplier data.

Pressures on the test rig were measured using pressure transducers, calibrated against a Betz manometer. The fan shaft speed was measured using a laser optical speed sensor, and the torque with an in line rotary torque transducer. Room pressure was measured with a precision barometer. Temperature measurements were taken at the orifice inlet and main fan inlet using PT 100 sensors. Humidity was also measured at the fan inlet. The velocity of the air through the heat exchanger was measured at the exit face on a grid of 16 
evenly spaced locations using a vane anemometer. All instruments were calibrated against traceable standards.

The procedure for a given flow rate was to take readings every second for ten seconds, and to repeat this to give two sets of readings that could be averaged. Anemometer readings were also taken twice and averaged.

\subsection{Processing and presentation of experimental results}

As previously mentioned, the flow rate was fixed and the pressure across the fan and heat exchanger was measured. This pressure will be abbreviated as $\Delta p_{s y s}$. The main components of $\Delta p_{s y s}$ are

$\Delta p_{s y s}=\Delta p_{f a n}+\Delta p_{p l}-\Delta p_{h e}(1)$

where $\Delta p_{f a n}$ is the pressure rise across the fan, $\Delta p_{p l}$ is the pressure rise across the plenum and $\Delta p_{h e}$ is the pressure drop across the heat exchanger.

$\Delta p_{h e}$ is composed of the pressure drop due to uniform flow $\Delta p_{\text {heu }}$ plus an additional drop due to the nonuniformity of the flow through the heat exchanger $\Delta p_{\text {henu }}$.

Rearranging equation (1) by combining $\Delta p_{\text {sys }}$ and $\Delta p_{\text {heu }}$ gives

$\Delta p_{\text {sys }}+\Delta p_{\text {heu }}=\Delta p_{\text {fan }}+\Delta p_{p l}-\Delta p_{\text {henu }}(2)$

Plotting $\Delta p_{f a n}+\Delta p_{p l}-\Delta p_{\text {henu }}$ gives a means of directly comparing the performance of different inclinations or plenum depths, accounting for all the factors that are changing.

The results required some processing before they could be presented in the form of equation (2). The goal was to present all data at standard conditions, as defined in [14]:

$\rho_{s t}=1.2 \mathrm{~kg} / \mathrm{m}^{3}$

$T_{s t}=293.15 \mathrm{~K}$

The data at test conditions needed to be corrected to standard conditions. For the fan, this meant density correction of the pressure rise across it, using the following relationship

$\rho_{t} / \Delta p_{t}=\rho_{s t} / \Delta p_{s t}(3)$

derived from the Euler equation for turbomachinery.

The pressure rise across the fan will not be completely Reynolds number independent, since the Reynolds number of the fan $R e_{d} \approx 0.9 \times 10^{6}$ which is below the threshold Reynolds number of $2.5 \times 10^{6}$ as noted by Cory [19]. The relationship between fan pressure rise and Reynolds number is unknown, so it is not possible to correct for it, although the impact of deviation from standard conditions in the tests is small. For the heat exchanger, the relationship between Fanning friction factor $f$ and Reynolds number is given by

$$
f \propto \operatorname{Re}_{L p}^{-0.39} \text { (4) }
$$

for $1000<R e_{D h}<4000 . R e_{D h}$ for this study was at the high end of this range. Equation (4) [20] is for a heat exchanger of a similar type to that used in this study.

Since head loss is directly proportional to Fanning friction factor

$$
\begin{aligned}
& \Delta p=\rho g h \\
& \Rightarrow \Delta p \propto \rho g f \\
& \Rightarrow \Delta p \propto \rho \operatorname{Re}^{-0.39}
\end{aligned}
$$

The result is

$\Delta p \propto \rho^{0.6}(5)$

Also

$\Delta p \propto \mu^{0.4}(6)$

The heat exchanger pressure loss is corrected using equations (5) and (6). 
The procedure for correcting the data is to first calculate the plenum recovery at test conditions using equation (2), with all parts of equation (2) being at test conditions. The plenum recovery is assumed to be constant, no matter what the air properties. This plenum recovery is then used again in equation (2) with all parts being at standard air conditions, to work out $\Delta p_{f a n}+\Delta p_{p l}-\Delta p_{\text {henu }}$.

The pressure drop across the heat exchanger is calculated based on the anemometer measurements taken at the heat exchanger exit. Jetting occurs at the heat exchanger exit, which means that the anemometer reads velocities larger than the true velocity, so the readings need to be scaled to match the mass flow rate as measured with the orifice plate. The corrected readings are then used with the heat exchanger supplier data to determine the pressure drop for each section, which is then averaged for the whole heat exchanger. This gives the total pressure loss across the heat exchanger. Subtracting the loss based on the average velocity gives $\Delta p_{\text {henu }}$.

\subsection{Experimental results}

The repeatability of the results was checked by conducting three experiments on three separate days at $30^{\circ}$ inclination. For each repeat, the exit assembly was disassembled and reassembled. The results are shown in Figure 4.

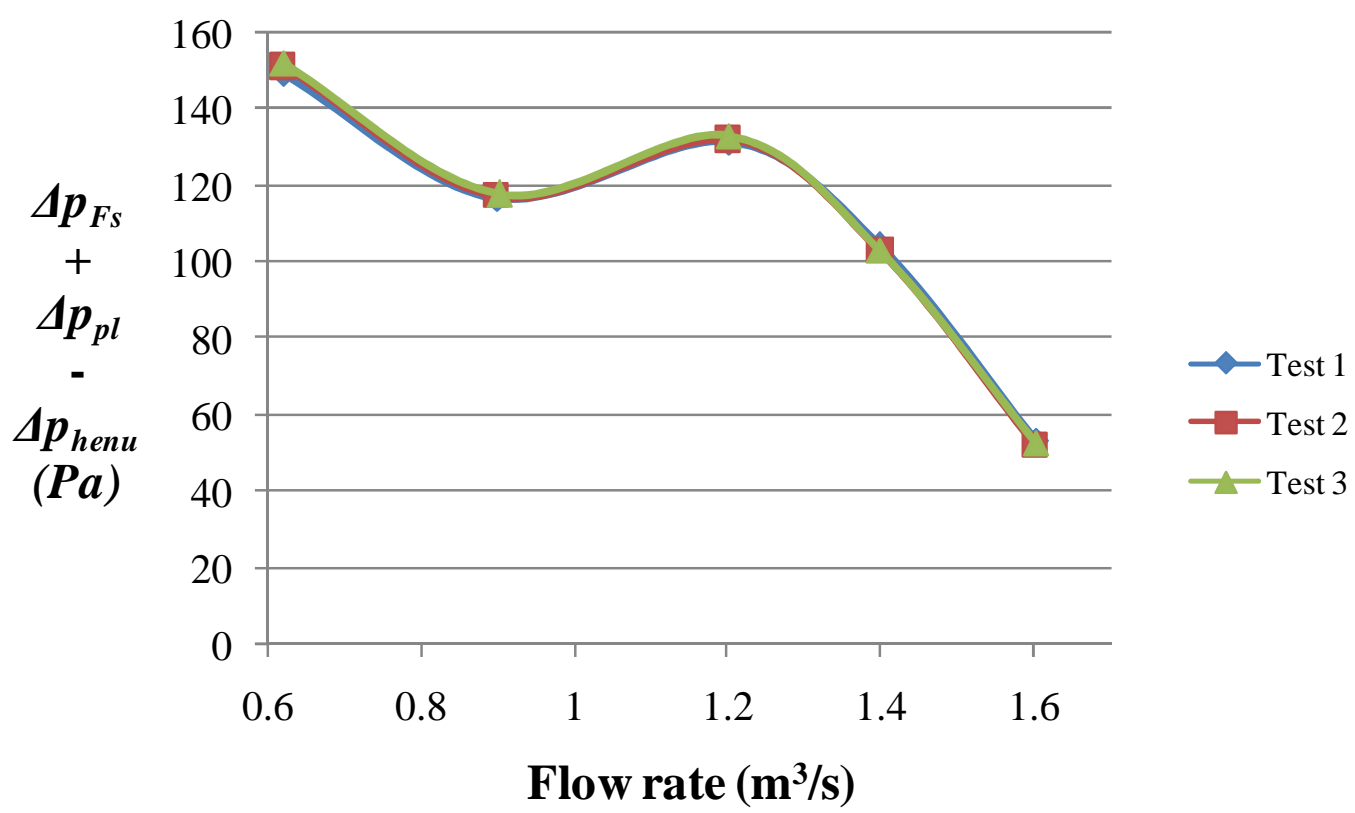

Figure 4 Repeatability of results at $30^{\circ}$ inclination

The error in the pressure measurements related to Figure 4 (and all other figures containing experimental pressure measurements) is $\pm 1.5 \mathrm{~Pa}$, which is small. This includes $1 \mathrm{~Pa}$ to account for the resolution of the Betz manometer used for calibration and $0.5 \mathrm{~Pa}$ for the accuracy of the pressure transducer. The error in the mass flow rate is also small. It is approximately $1 \%$, resulting from uncertainty in the discharge coefficient of the orifice plate.

The results for inclination of the heat exchanger and for various plenum depths without inclination are shown in Figure 5. In Figure $5 \mathrm{~b}$ ) the plenum depths $x_{p l}$ were non dimensionalised by dividing by the fan casing diameter $d_{f c}$. The plenum depth for both inclined and non inclined cases is defined as the distance from the centre of the exit plane of the fan to the centre of the inlet plane of the heat exchanger. The exit 
plane of the fan is the plane that just touches the furthest downstream point of the trailing edges of the fan blades.

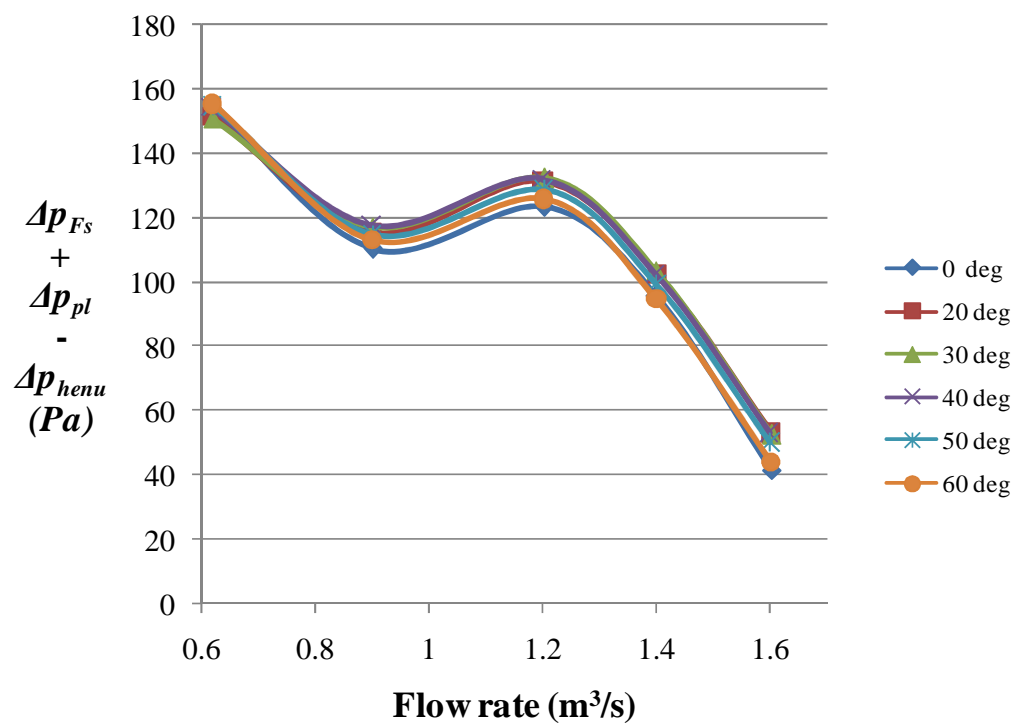

a)

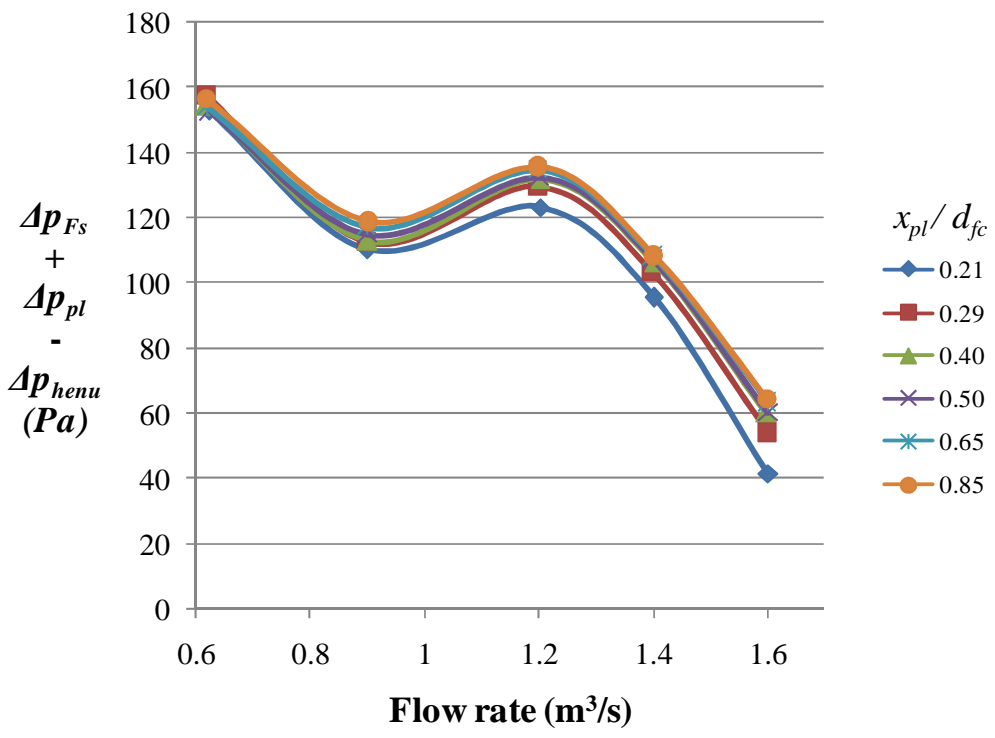

b)

Figure 5 Effect of a) inclination of heat exchanger and b) plenum depth without inclination.

A higher pressure value in Figure 5 represents improved performance, as it represents an improvement in pressure rise across the system for a given flow rate. Figure 5 shows that the effect of inclination is negligible in the mixed flow region of the fan characteristic, for both inclined and non inclined cases. It also shows that the optimum inclination angle is somewhere around $20^{\circ}$ to $40^{\circ}$ inclination.

Figure 6 shows the results at $1.4 \mathrm{~m}^{3} / \mathrm{s}$ for both the inclined and non inclined cases. (A flow rate of $1.4 \mathrm{~m}^{3} / \mathrm{s}$ corresponds to a mean air velocity of $6.3 \mathrm{~m} / \mathrm{s}$ through the heat exchanger). To facilitate comparison, both sets of results are presented in terms of non dimensionalised plenum depth. The Figure shows that $30^{\circ}$ is the optimum inclination angle. It is also apparent that increasing the depth without inclination improves 
performance more than through inclination alone. It also shows that the optimum plenum depth is 0.65 fan diameters or greater - the critical minimum plenum depth. The heat exchanger used has a low pressure loss factor, so this critical minimum depth agrees with the findings of [1] that critical minimum depth increases with decreasing heat exchanger restriction.

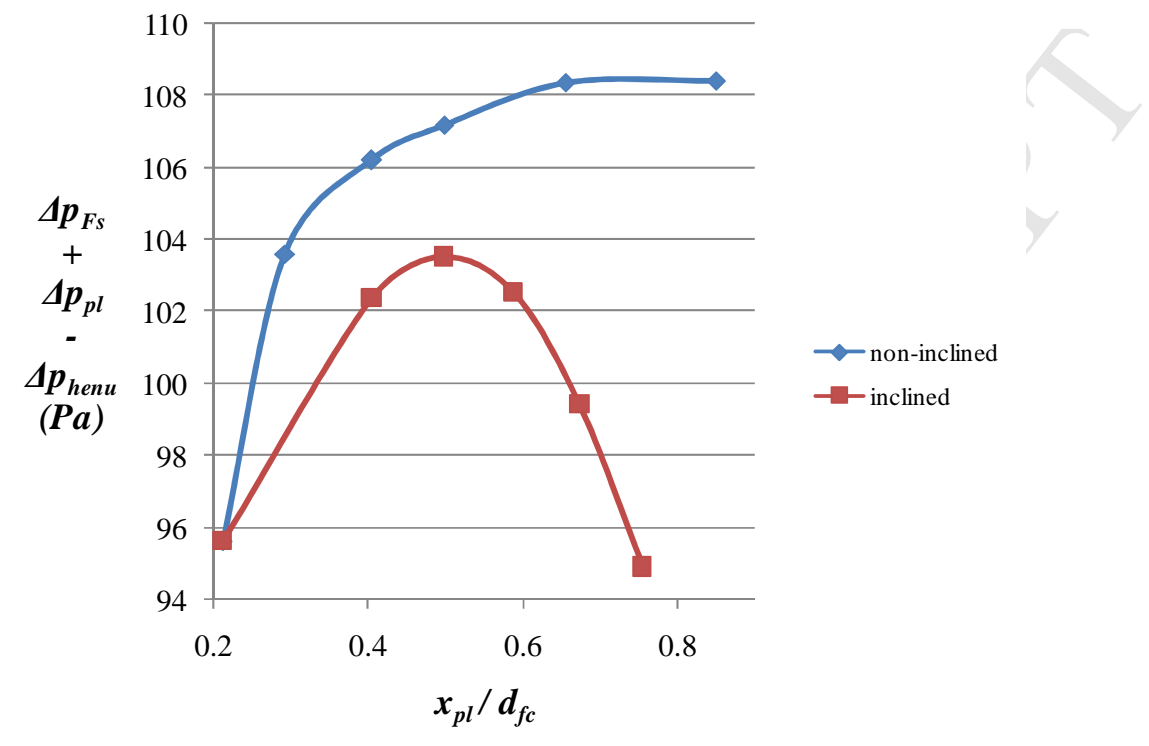

Figure 6 Effects of inclination and depth at $1.4 \mathrm{~m}^{3} / \mathrm{s}$

The thermal performance of a number of cases of interest was calculated, using supplier data for the heat exchanger thermal performance and the heat exchanger velocity measurements. Further details on how to calculate the thermal performance of heat exchangers are given in Khaled et al [21]. The thermal performance was determined for each velocity measurement square of the heat exchanger and the results summed over the entire face. The case with no inclination and a plenum depth of 0.21 fan diameters was used as a baseline. The results are shown in Table 1. The results show that the effects of inclination and increased plenum depth on thermal performance are small.

Table 1 Thermal performance improvement due to inclination and increased plenum depth

\begin{tabular}{|c|c|c|c|c|c|}
\hline Inclination angle $\left(^{\circ}\right)$ & $\boldsymbol{x}_{\boldsymbol{p l}} / \boldsymbol{d}_{\boldsymbol{f} \boldsymbol{c}}$ & Flow rate $\left(\mathbf{m}^{\mathbf{3}} / \mathbf{s}\right)$ & $\boldsymbol{\%}$ change in flow & $\boldsymbol{Q}(\mathbf{W})$ & $\boldsymbol{\%}$ change in $\boldsymbol{Q}$ \\
\hline 0 & 0.21 & 1.359 & $\mathrm{n} / \mathrm{a}$ & 33838 & $\mathrm{n} / \mathrm{a}$ \\
\hline 30 & 0.50 & 1.382 & 1.69 & 34013 & 0.52 \\
\hline 0 & 0.65 & 1.397 & 2.80 & 34215 & 1.12 \\
\hline
\end{tabular}

A final experimental consideration is the significance of inlet losses on the air side of the heat exchanger passages. Since the optimum configuration lay in the range $20-40^{\circ}$ of inclination, it was anticipated that the inlet losses for this configuration would be very small. In order to achieve a significant level of inlet loss and to compare with other published studies [9-11], the inlet loss for an inclination of $60^{\circ}$ was measured against the baseline non-inclined case. To isolate the effects of inclination only, and remove the impact of swirling flow, the main fan was removed and the pressure drop across the heat exchanger was measured for the $60^{\circ}$ inclination and for the non-inclined heat exchanger in a plenum of equivalent depth. The results were that the additional inlet losses due to $60^{\circ}$ inclination compared to $0^{\circ}$ were approximately equal to the dynamic pressure of the air, for uniform non swirling flow entering the heat exchanger. 


\section{Numerical study}

A CFD study was conducted using ANSYS CFX to investigate how the flow changes in the plenum with inclination. The model is shown in Figure 7. All simulations were conducted at $1.4 \mathrm{~m}^{3} / \mathrm{s}$.

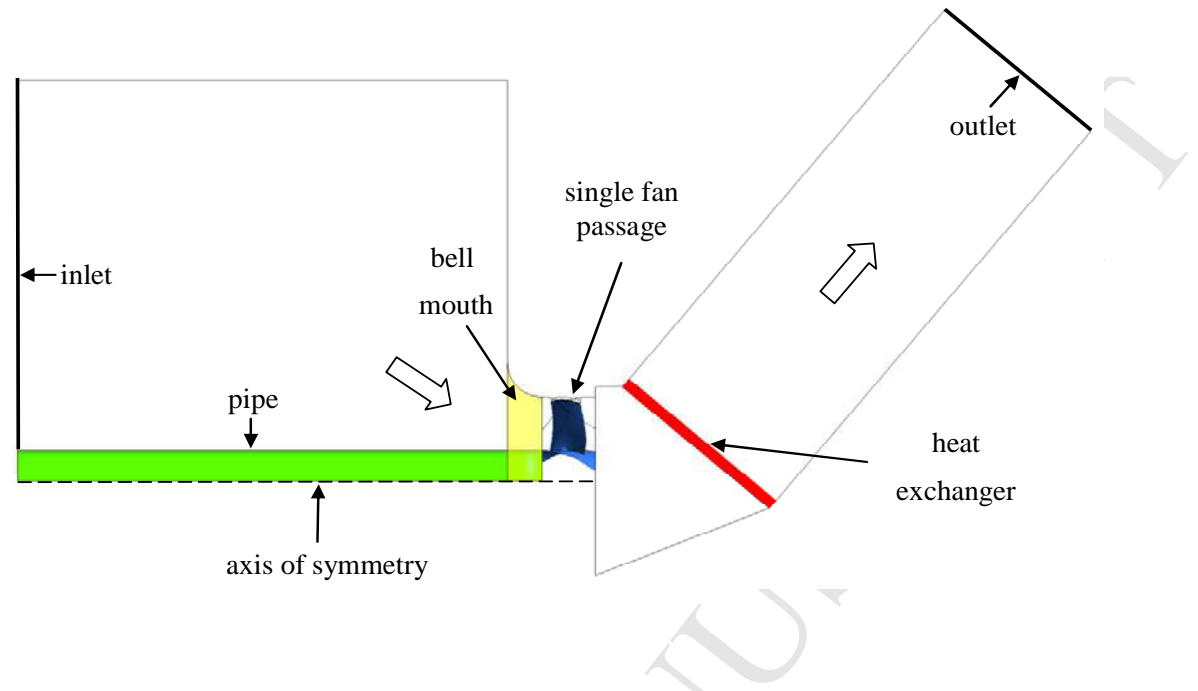

Figure 7 CFD model

A pipe was included with the same diameter as the fan hub, directly in front of the hub, as on the test rig. This was to provide a wall for flow to attach to as it entered the fan. More information on modelling axial flow fans can be found in Liu et al [22]. In this work the fan was modelled using a mixing plane multiple reference frame model. This means that the flow was circumferentially averaged at the inlet and outlet of the fan domain. Only one fan passage was modelled, and one quarter of the upstream domain, as the flow was axisymmetric up to the fan exit. Gullberg et al [23] found the multiple reference frame model to be very accurate for axial fan simulations, provided that the fan domain boundaries are located far enough away from the blades.

The heat exchanger was modelled as a porous medium, with the flow constrained to move in a direction perpendicular to the inlet face. The flow through the airside passages was not modelled in detail, so inlet losses were not included in the CFD model.

In the simulations the Reynolds averaged Navier Stokes equations were solved. The flow was modelled as being steady, viscous, compressible and isothermal. The turbulence model used was $k \omega \mathrm{SST}$. The advection scheme used was formally second order accurate in space.

The fan was meshed with a structured mesh using ANSYS Turbogrid. Each passage had approximately one million cells. A structured grid was also used for the outer domain, with approximately two million cells.

Sensitivity studies were conducted for the simulations using the $40^{\circ}$ inclination configuration only, to ensure that the results of interest were independent of residual target, outer domain size, turbulence intensity, fan blade cell $\mathrm{y}^{+}$and independent of the number of cells in the fan and outer domains. The predicted quantities used to evaluate the quality of the simulations were the mass flow rate through the domain, $\Delta p_{s y s}$, the heat exchanger pressure loss, the fan static pressure rise, the pressure distribution along the plenum walls and two velocity profiles across the exit of the heat exchanger. A selection of results from the sensitivity study are presented in Tables 2 and 3. Table 2 shows the sensitivity of some of these quantities to variations in the target RMS value of residuals from the mass and momentum equations. The results demonstrate that the predictions were quite insensitive to the range of residual values assessed and a target RMS residual value of 5E10-5 was chosen for the remainder of the study. 
Table 2 Sensitivity to RMS residual target

\begin{tabular}{|c|c|c|c|}
\hline $\begin{array}{c}\text { Target } \\
\text { RMS } \\
\text { residual }\end{array}$ & $\boldsymbol{\Delta} \boldsymbol{p}_{\boldsymbol{F s}}(\mathrm{Pa})$ & $\boldsymbol{\Delta} \boldsymbol{p}_{\text {he }}(\mathrm{Pa})$ & $\boldsymbol{\Delta} \boldsymbol{p}_{\text {sys }}(\mathrm{Pa})$ \\
\hline 1.E-04 & 111.16 & 115.32 & 3.05 \\
\hline 5.E-05 & 110.95 & 115.33 & 3.59 \\
\hline 5.E-06 & 110.43 & 115.29 & 3.92 \\
\hline
\end{tabular}

Table 3 Sensitivity to grid density

\begin{tabular}{|c|c|c|c|c|c|}
\hline $\begin{array}{c}\text { inlet domain } \\
\text { cell count }\end{array}$ & $\begin{array}{c}\text { outlet domain } \\
\text { cell count }\end{array}$ & $\begin{array}{c}\text { plenum domain } \\
\text { cell count }\end{array}$ & $\boldsymbol{\Delta p}_{\boldsymbol{F s}}(\boldsymbol{P a})$ & $\Delta \boldsymbol{p}_{\boldsymbol{h e}}(\boldsymbol{P a})$ & $\boldsymbol{\Delta} \boldsymbol{p}_{\text {sys }}(\boldsymbol{P a})$ \\
\hline 80,000 & 43,000 & 766,000 & 110.71 & 115.23 & 4.5408 \\
\hline 163,000 & 87,000 & $1,586,000$ & 110.75 & 115.29 & 4.5224 \\
\hline 379,000 & 198,000 & $3,560,000$ & 109.77 & 115.31 & 5.5818 \\
\hline
\end{tabular}

Table 3 shows the impact of grid density on the same three quantities. The impact of varying grid density on fan pressure rise and heat exchanger pressure drop is shown to be very small. Therefore the configuration with $1.6 \mathrm{M}$ cells in the plenum was chosen as a satisfactory balance between grid resolution and computational efficiency.

\subsection{Model validation}

The CFD model was validated by taking pressure measurements along the side walls of the plenum in the experiments. A total of 18 tappings were located along the side and base walls of the plenum, on lines midway along the walls. For example, the comparison for one side wall of the plenum is shown in Figure 8 , for $40^{\circ}$ inclination. There is some discrepancy between the CFD and the experiment, especially towards the corners of the plenum. There were insufficient experimental measurement points to be able to evaluate the CFD results close to the corners. The discrepancy could be due to the two equation turbulence model used. A Reynolds Stress model was investigated but convergence problems were encountered. More complex turbulence models such as Large Eddy Simulation were considered to be too computationally expensive to be used in the study. 


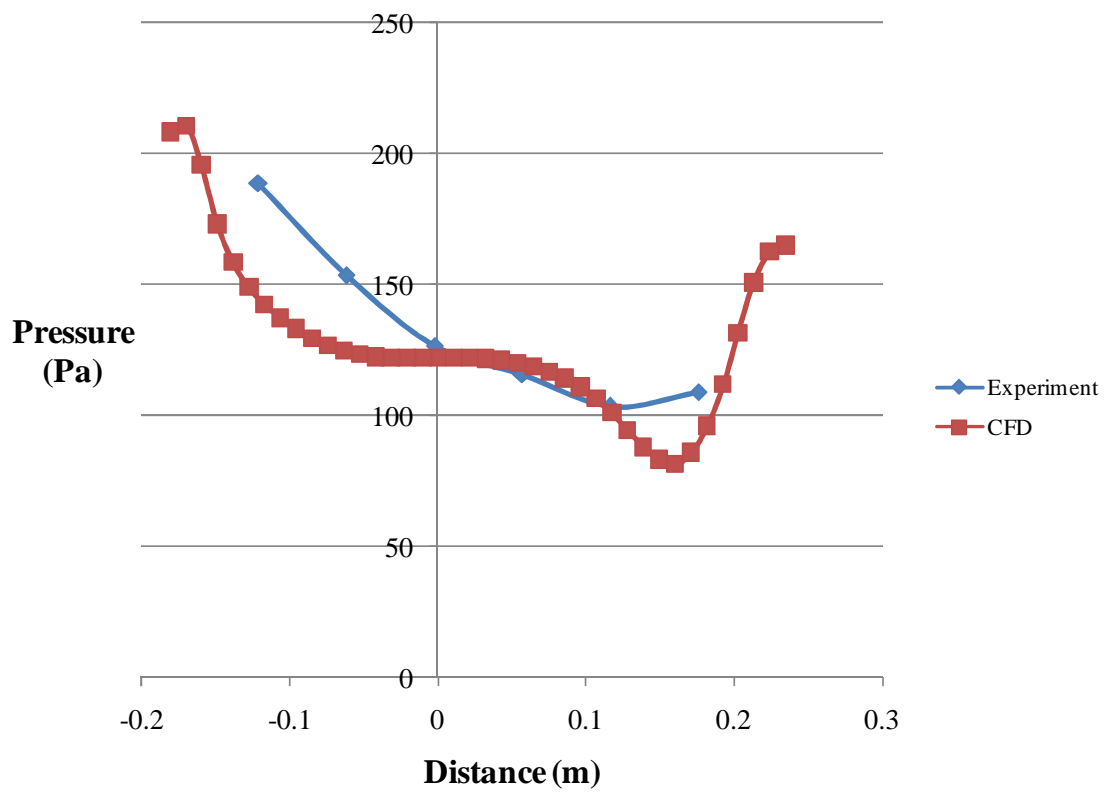

Figure 8 Validation of CFD - pressure midway along plenum side wall for $40^{\circ}$ inclination

Further validation was achieved by comparing the pressure loss across the system with the experiment, for different inclination angles. This is shown in Figure 9. There is a pressure loss because at $1.4 \mathrm{~m}^{3} / \mathrm{s}$, the auxiliary fan is boosting the performance of the main fan to achieve that flow rate.

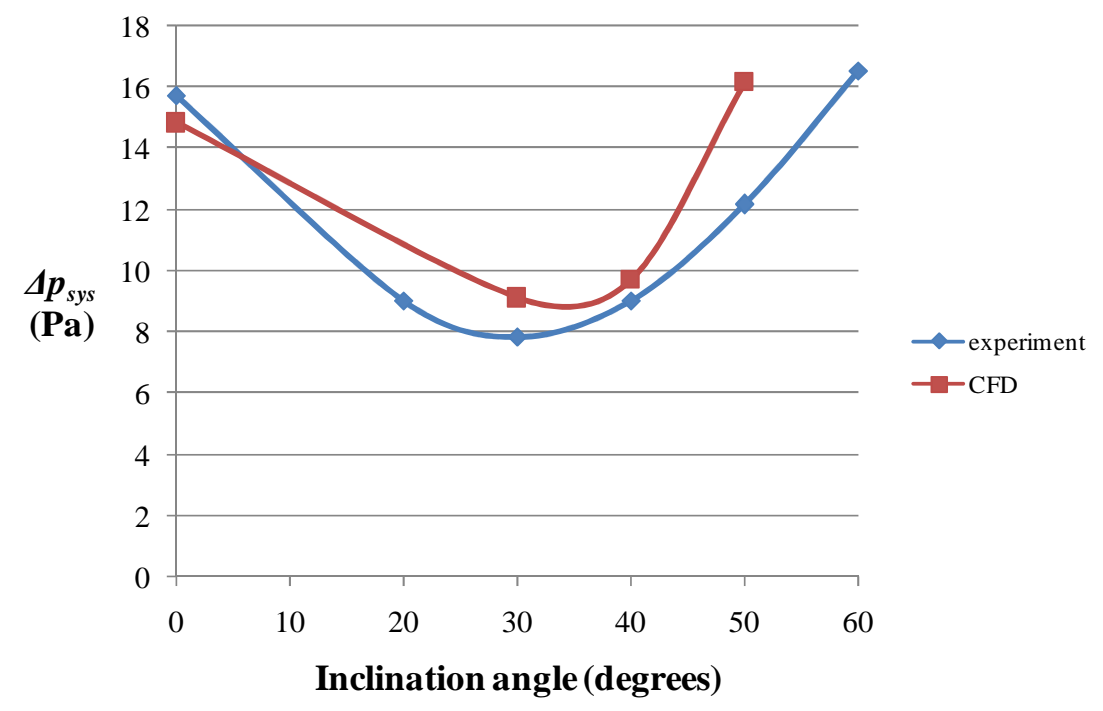

Figure 9 Validation of CFD - system pressure loss at $1.4 \mathrm{~m}^{3} / \mathrm{s}$

In Figure 9 the results compare well between the experiment and the CFD. The CFD model did not account for inlet losses due to incidence at entry to the heat exchanger fins, therefore, as the shape of the two lines is similar, this suggests that inlet losses do not change significantly with angle. This can be explained by the fact that the flow entering the heat exchanger is swirling, no matter what the inclination angle. 
The velocity distribution measured at the heat exchanger exit was also compared with the CFD. This is shown in Figure 10. The patterns are similar, although the range of velocities is higher for the CFD.

a)

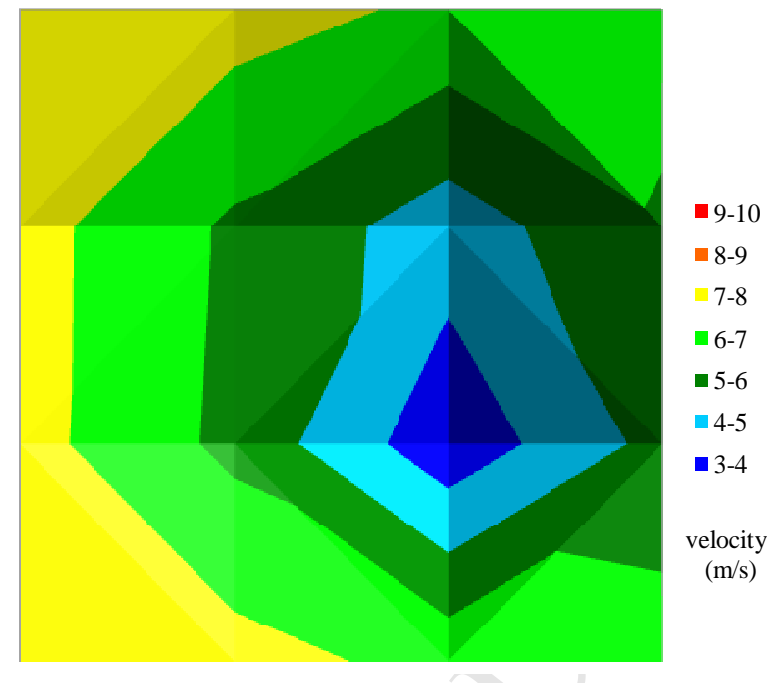

b)

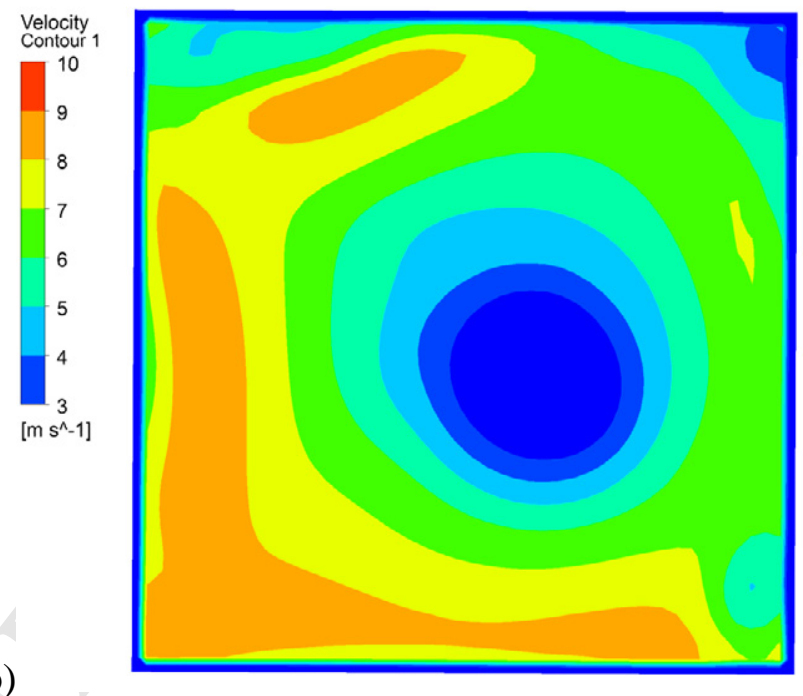

Figure 10 Heat exchanger exit velocity distribution at $30^{\circ}$ inclination for a) experiment and b) CFD

\subsection{CFD results}

Figure 11 is a plot of the area averaged pressure rise across the plenum from the fan outlet to the heat exchanger inlet. Also plotted is the fan static pressure rise, which is the area averaged static pressure at fan outlet minus the mass flow averaged total pressure at the outer domain inlet. 


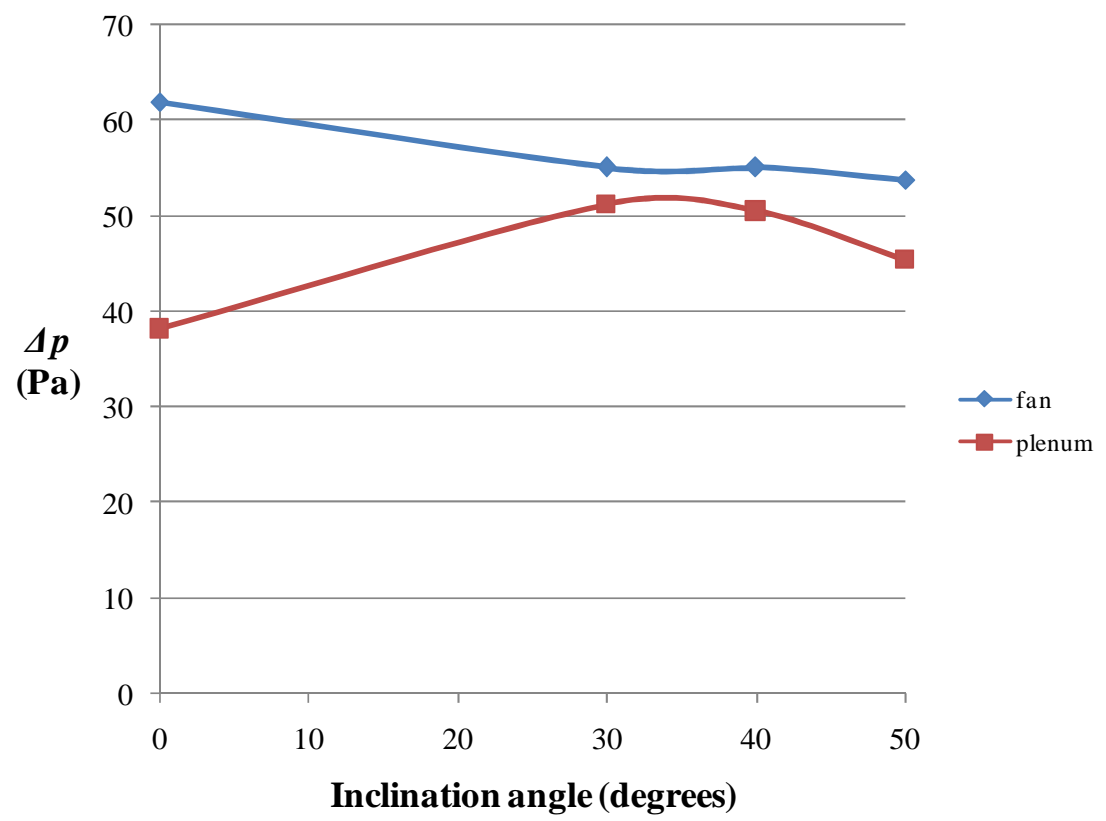

Figure 11 Simulated pressure rise across fan and plenum

In this study, as the heat exchanger inclination angle increases, the plenum depth also increases. From Figure 11 it can be concluded that the closer the heat exchanger is to the fan, the higher the static pressure rise across the fan. It also shows that pressure recovery in the plenum increases with plenum depth up to approximately $30^{\circ}$ to $40^{\circ}$ inclination, where it starts to reduce. 
a)

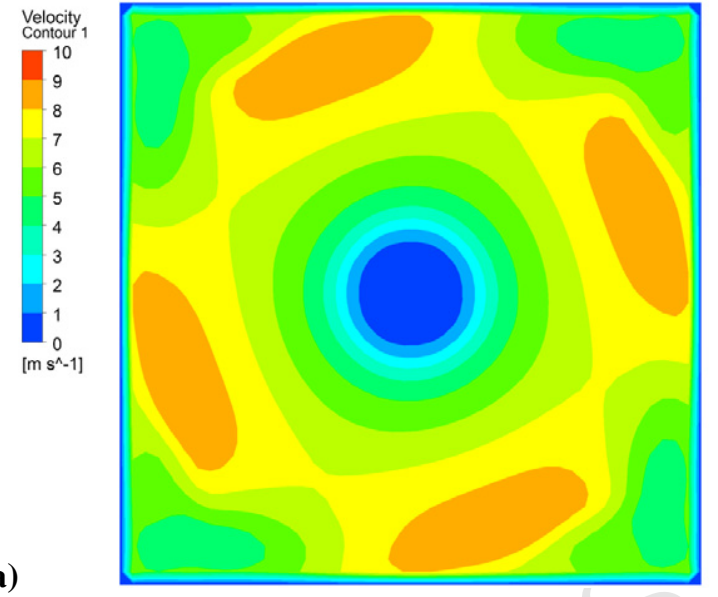

b)
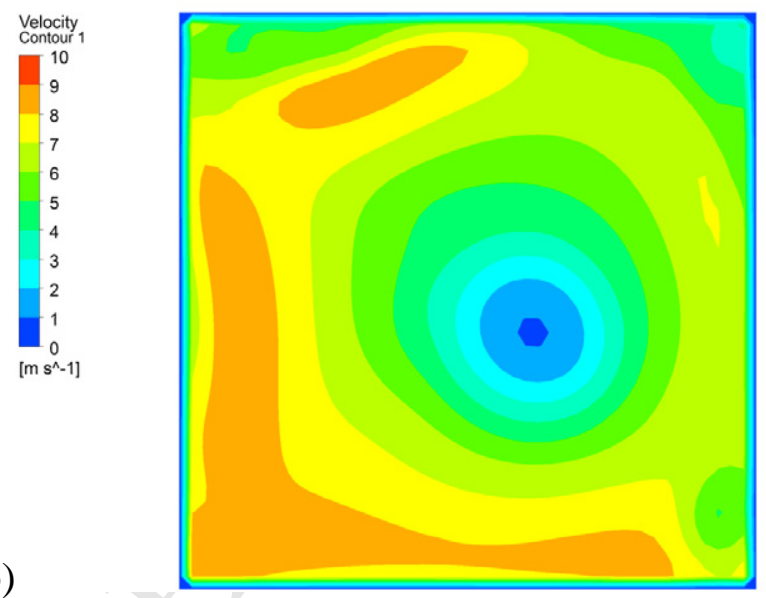

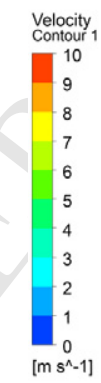

c)

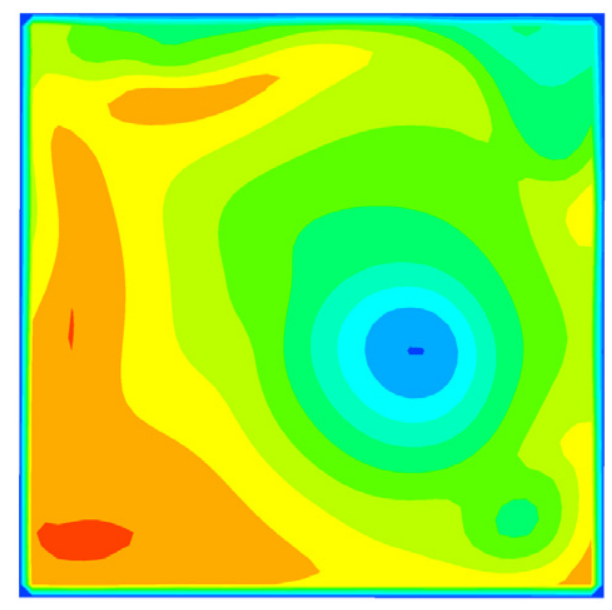

Figure 12 Simulated heat exchanger exit velocity plots at $1.4 \mathrm{~m}^{3} / \mathrm{s}$ for a) $0^{\circ}$ inclination, b) $30^{\circ}$ inclination and c) $50^{\circ}$ inclination 


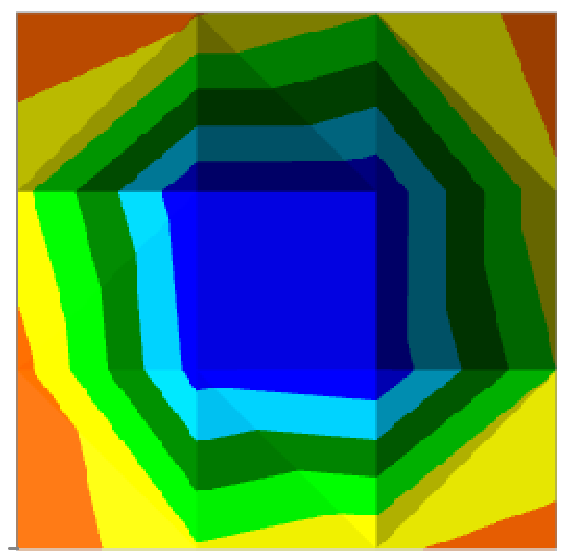

$$
\begin{gathered}
\square-6 \\
\square 4-5 \\
-3-4 \\
\square 2-3 \\
\square 1-2 \\
\square 0-1 \\
\square-1-0
\end{gathered}
$$

\section{velocity}

$(\mathrm{m} / \mathrm{s})$

a)

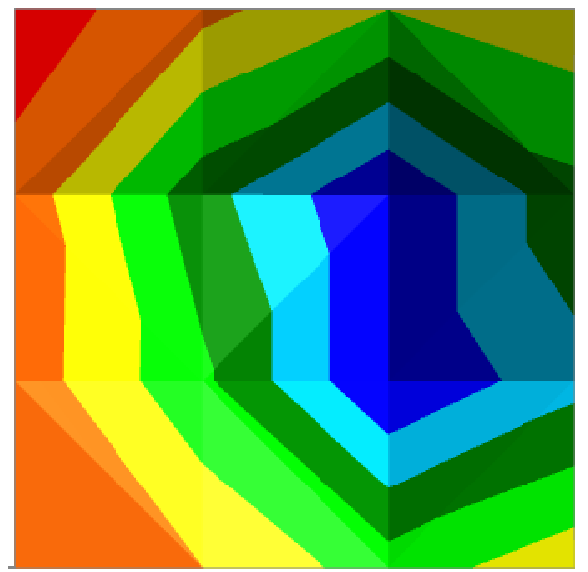

- 5-6

$\square-5$

$=3-4$

$=2-3$

- $1-2$

$=0-1$

- $-1-0$

velocity

$(\mathrm{m} / \mathrm{s})$

b)

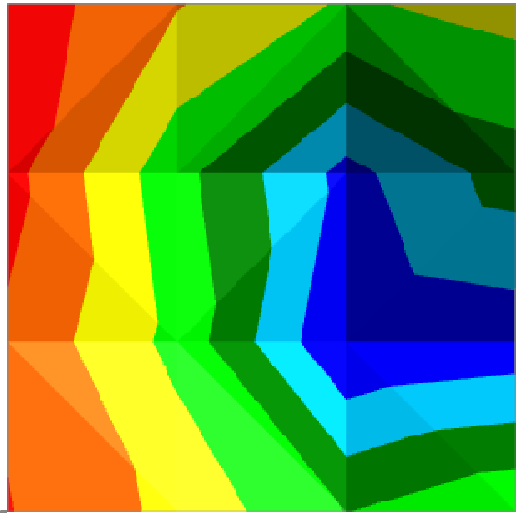

$$
\begin{gathered}
\square-6 \\
\square-5 \\
\square-4 \\
\square 2-3 \\
\square 1-2 \\
\square 0-1 \\
\square-1-0 \\
\text { velocity } \\
(\mathrm{m} / \mathrm{s})
\end{gathered}
$$

c)

Figure 13 Measured heat exchanger exit velocity plots at $0.62 \mathrm{~m}^{3} / \mathrm{s}$ for a) $0^{\circ}$ inclination, b) $30^{\circ}$ inclination and c) $50^{\circ}$ inclination 
The final issue to discuss is how the flow through the heat exchanger changes with inclination. Simulated velocity contours at the heat exchanger exit are shown for an axial fan operating point at different inclination angles in Figure 12. The results show that the low velocity core at the centre of the heat exchanger moves to one side as the heat exchanger is inclined. This occurs because of the swirl of the flow exiting the fan and its interaction with the corners of the square duct and the inclined heat exchanger downstream.

In Figure 13, measured velocity contours were plotted for a mixed flow fan operating point over a range of inclination angles. The effect is similar to that shown for the axial flow operating point in Figure 12.

Figure 14 is a plot of streamlines in the plenum of the ACHE at $30^{\circ}$ inclination, viewed from the exit of the downstream duct. On the right hand side, the flow bypasses the heat exchanger inlet, due to the swirl of the flow exiting the fan. On the left hand side, the swirl of the flow means that the flow is more aligned with the airside passages. Therefore on that side most flow passes directly through the heat exchanger rather than over its face.

Most turbocharged engine cooling systems have a charge air cooler as well as a jacket water cooler. These are often located side by side. If one of the two coolers has a significantly worse performance than the other, then it may be beneficial with inclined heat exchangers to locate that cooler on the side where the flow is more likely to pass directly through rather than bypass the inlet face. This may enable the cooling system to operate in an environment with a higher ambient temperature.
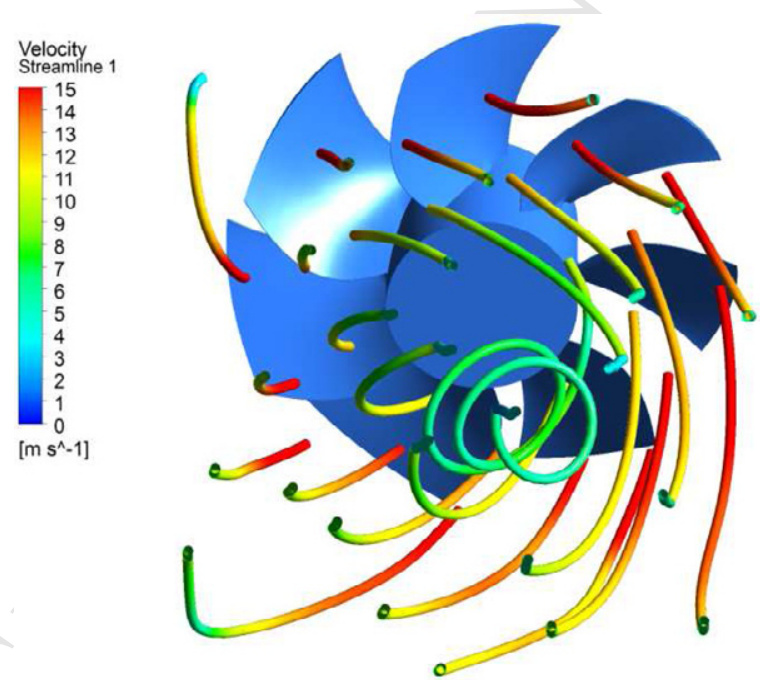

Figure 14 Plenum streamlines at 30 degrees inclination, viewed from the exit of the downstream duct

\section{Conclusions}

The main conclusion of the study is that inclination leads to a small increase in the thermal performance of the ACHE of approximately $0.5 \%$ for the optimum inclination angle of $30^{\circ}$, when compared with the baseline case of a shallow plenum. Increasing the depth of the plenum is slightly more effective, giving a performance increase of $1 \%$ for a plenum 0.65 fan diameters deep.

Of more significance is what happens to the flow through the heat exchanger as it is inclined. The tendency is for the low velocity core to move to one side as the inclination angle is increased. This could lead to improvements in the performance of the cooling system if the ACHE consisted of multiple side by side heat exchangers. In that case the designer could locate the performance limiting component on the side opposite that of the low velocity core. 


\section{Acknowledgements}

The authors would like to thank ANSYS Inc. for supporting this research project through the use of the CFX and TurboGrid software. Thanks also go to FG Wilson for supporting the work carried out in this project. 


\section{References}

[1] C.J. Meyer, D.G. Kröger, Plenum chamber flow losses in forced draught air-cooled heat exchangers, Appl.Therm.Eng. 18 (9-10) (1998) 875-893.

[2] R.J. Berryman, C.M.B. Russell, The effect of maldistribution of airflow on air-cooled heat exchanger performance, ASME HTD. 75 (1987) 19-23.

[3] M.G. Beiler, D.G. Kroger, Thermal performance reduction in air-cooled heat exchangers due to nonuniform flow and temperature distributions, Heat Transfer Eng. 17 (1) (1996) 82-92.

[4] T.J. Rabas, The effect of nonuniform inlet flow and temperature distribution on the thermal performance of air-cooled condensers, ASME HTD. 75 (1987) 29-35.

[5] T.J. Fagan, The effects of air flow maldistributions on air-to-refrigerant heat exchanger performance, ASHRAE Trans. 86 (2) (1980) 699-713.

[6] C. T'Joen, M. De Paepe, F. Vanhee, Heat exchanger behavior in non uniform flow, Exp. Heat Trans. 19 (4) (2006) 281-296.

[7] T. Hallqvist, The Cooling Airflow of Heavy Trucks - a Parametric Study, SAE Int. J. Commer. Veh. 1 (1) (2009) 119-133.

[8] D.G. Kröger, Air-cooled Heat Exchangers And Cooling Towers: Thermal-flow Performance Evaluation And Design Volume 2,Pennwell, Tulsa, Oklahoma, USA, 2004.

[9] M.R. Nichols, Investigation of flow through an intercooler set at various angles to the supply duct, Wartime Report, Langley Meml. Aeronaut. Lab., Langley Field, Virginia, USA. (1942).

[10] H. Kanematsu, K. Murakami, Characteristics of inclined fin-tube heat exchanger for compact air conditioner, Proc. of ASME Int. Mech. Eng. Congr. and Exhib. (2002) 55-61.

[11] C.J. Meyer, D.G. Kröger, Air-cooled heat exchanger inlet flow losses, Appl. Therm. Eng. 21 (2001) 771-786.

[12] A. Elgowalny, CFD applied to heat pump system design, 37th Intersoc. Energy Convers. Eng. Conf. (2002) 470-474.

[13] X. Song, D. Huang, X. Liu, Q. Chen, Effect of non-uniform air velocity distribution on evaporator performance and its improvement on a residential air conditioner, Appl. Therm. Eng. 40 (2012) 284-293.

[14] N. Kim, D. Kim, Y. Choi, H. Byun, Air-side heat transfer and pressure drop characteristics of louverfinned aluminium heat exchangers at different inclination angles, J. Therm. Science Technol. 4 (3) (2009) $350-361$.

[15] M. Kim, B. Youn, C.W. Bullard, Effect of inclination on the air-side performance of a brazed aluminium heat exchanger under dry and wet conditions, Int. J. Heat and Mass Transf. 44 (24) (2001) 4613-4623.

[16] ISO 5801:2008 Industrial fans - Performance testing using standardized airways, (2008). 
[17] ISO 15377 Measurement of fluid flow by means of pressure-differential devices - Guidelines for the specification of orifice plates, nozzles and Venturi tubes beyond the scope of ISO 5167, (2007).

[18] R.J. Berryman, C.M.B. Russell, Airflow in air-cooled heat exchangers, Heat Transf. Eng. 8 (4) (1987) 40-44.

[19] W.T.W. Cory, Fans and Ventilation: A Practical Guide, Elsevier, Amsterdam, Netherlands, 2005.

[20] C.J. Davenport, Correlations for heat transfer and flow friction characteristics of louvered fin, AIChE Symp. Ser. 79 (1983) 19-27.

[21] M. Khaled, F. Harambat, H. Peerhossaini, Analytical and empirical determination of thermal performance of louvered heat exchanger - Effects of air flow statistics, Int. J. Heat and Mass Transf. 54 (2011) 356-365.

[22] S. H. Liu, R. F. Huang, C. A. Lin, Computational and experimental investigations of performance curve of an axial flow fan using downstream flow resistance method, Exp. Therm. Fluid Science 34 (2010) 827-837.

[23] P. V. Gullberg, L. Löfdahl, P. Nilsson, S. Adelman, Continued Study of the Error and Consistency of Fan CFD MRF Models, SAE Technical Paper 2010-01-0553. (2010).

\section{Nomenclature}

Latin symbols

$d$ : diameter $(\mathrm{m})$

$f$ : Fanning friction factor

$g$ : acceleration due to gravity $\left(\mathrm{ms}^{-2}\right)$

$p$ : pressure $(\mathrm{Pa})$

$Q$ : heat transfer rate $(\mathrm{W})$

Re: Reynolds number

$T$ : temperature (K)

$x$ : depth (m)

$y^{+}:$dimensionless wall distance

Greek symbols

$\Delta$ : differential

$\theta$ : inclination angle $\left({ }^{\circ}\right)$

$\rho$ : density $\left(\mathrm{kgm}^{-3}\right)$

Subscripts

$d$ : diameter

$D h$ : hydraulic diameter

$f c$ : fan casing

Fs: fan static

$h e$ : heat exchanger

henu: heat exchanger non-uniform

heu: heat exchanger uniform

$L p$ : louver pitch

$p l$ : plenum 
$s t:$ standard

sys: system

$t$ : test

Abbreviations

ACHE: air-cooled heat exchanger

CFD: computational fluid dynamics

RMS: root mean square

SST: shear stress transport 